\title{
Chlorella sorokiniana cultivation in cheese whey for $\beta$-galactosidase production
}

\author{
Cultivo da microalga Chlorella sorokiniana em soro de queijo para produção de $\beta$-galactosidase
}

Cultivo de Chlorella sorokiniana en suero de queso para la producción de $\beta$-galactosidasa

Received: 09/17/2021 | Reviewed: 09/25/2021 | Accept: 09/26/2021| Published: 09/27/2021

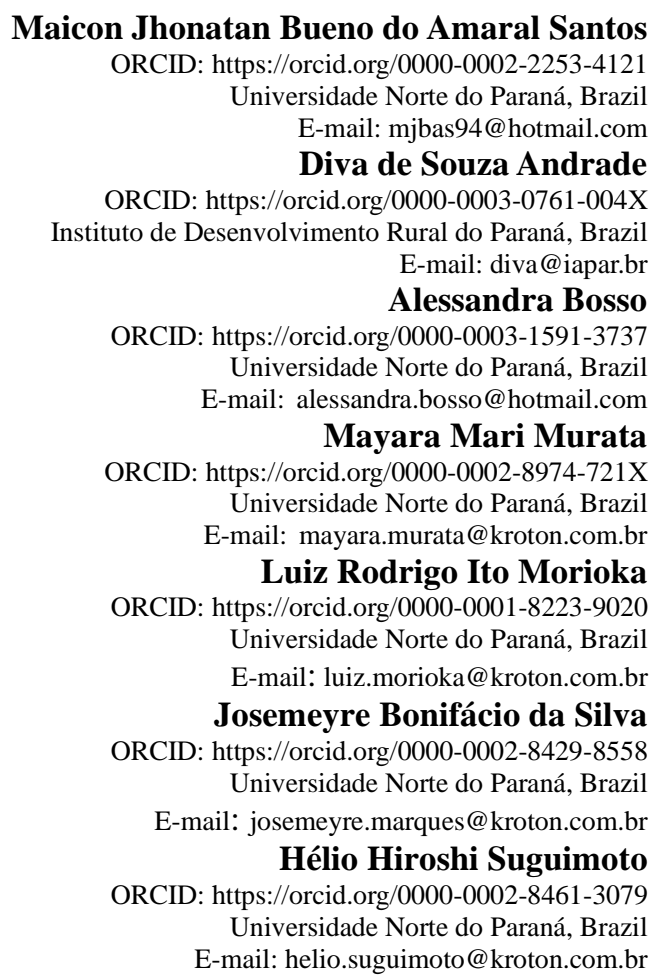

\begin{abstract}
Biotechnological processes with microalgae with the aim to achieve high biomass yields must choose the appropriate nutrients and physicochemical parameters, taking into account the specific characteristics of each species to determine the basic needs for its growth. In the present study, the better growth condition of Chlorella sorokiniana IPR 7104 was optimized to reach the maximum beta-galactosidase production. The cheese whey concentration $(\%)$, temperature $\left({ }^{\circ} \mathrm{C}\right)$ and $\mathrm{pH}$ were factors investigated and a Box-Behnken Design (BBD) approach was implemented using Statistica 7.0 software. We observed that the cultivation condition to Chlorella sorokiniana IPR 7104 was the heterotrophic, which showed the major enzymatic activity, consequently a lower residual lactose content. Under heterotrophic conditions (without light) the $\beta$-galactosidase activity increased linearly until the 8 th day. Biomass production grew linearly on the 12th day. The microalgae consumed $89.6 \%$ of lactose in 3 days, showing a high capacity to metabolize this disaccharide, through $\beta$-galactosidase synthesis. The maximum $\beta$-galactosidase production by Chlorella sorokiniana IPR 7104, in heterotrophic conditions and using cheese whey as carbon source, is obtained using the following conditions: $30^{\circ} \mathrm{C}$ temperature, concentration of ethanol at $20 \%$ and time of $4 \mathrm{~min}$.
\end{abstract}

Keywords: Biotechnological process; Microalgae; Cultivation conditions; Biomass.

\section{Resumo}

Os processos biotecnológicos com microalgas com o objetivo de alcançar elevados rendimentos de biomassa devem escolher os nutrientes e parâmetros físico-químicos adequados, tendo em conta as características específicas de cada espécie para determinar as necessidades básicas para o seu crescimento. No presente estudo, a melhor condição de crescimento de Chlorella sorokiniana IPR 7104 foi otimizada para atingir a produção máxima de beta-galactosidase. A concentração de soro de queijo $(\%)$, temperatura $\left({ }^{\circ} \mathrm{C}\right)$ e $\mathrm{pH}$ foram fatores investigados e um delineamento de BoxBehnken Design (BBD) foi conduzido usando o software Statistica 7.0. Observamos que a condição de cultivo para Chlorella sorokiniana IPR 7104 foi a heterotrófica, que apresentou maior atividade enzimática, consequientemente menor teor de lactose residual. Em condições heterotróficas (sem luz) a atividade da $\beta$-galactosidase aumentou linearmente até o $8^{\circ}$ dia. A produção de biomassa cresceu linearmente no $12^{\circ}$ dia. A microalga consumiu $89,6 \%$ da 
lactose em 3 dias, apresentando alta capacidade de metabolizar esse dissacarídeo, por meio da síntese de $\beta$ galactosidase. A produção máxima de $\beta$-galactosidase por Chlorella sorokiniana IPR 7104, em condições heterotróficas e utilizando soro de queijo como fonte de carbono, é obtida nas seguintes condições: temperatura de 30 ${ }^{\circ} \mathrm{C}$, concentração de etanol a $20 \%$ e tempo de 4 min.

Palavras-chave: Processo biotecnológico; Microalgas; Condições de cultivo; Biomassa.

\section{Resumen}

Los procesos biotecnológicos con microalgas con el objetivo de lograr altos rendimientos de biomasa deben elegir los nutrientes y parámetros fisicoquímicos adecuados, teniendo en cuenta las características específicas de cada especie para determinar las necesidades básicas para su crecimiento. En el presente estudio, se optimizó la mejor condición de crecimiento de Chlorella sorokiniana IPR 7104 para alcanzar la producción máxima de beta-galactosidasa. La concentración de suero de queso $(\%)$, la temperatura $\left({ }^{\circ} \mathrm{C}\right)$ y el $\mathrm{pH}$ fueron factores investigados y se implementó un enfoque Box-Behnken Design (BBD) utilizando el software Statistica 7.0. Observamos que la condición de cultivo de Chlorella sorokiniana IPR 7104 fue la heterotrófica, la cual mostró la mayor actividad enzimática, consecuentemente un menor contenido de lactosa residual. En condiciones heterótrofas ( $\sin$ luz), la actividad de la $\beta$-galactosidasa aumentó linealmente hasta el octavo día. La producción de biomasa creció linealmente el día 12. Las microalgas consumieron el $89,6 \%$ de lactosa en 3 días, mostrando una alta capacidad para metabolizar este disacárido, a través de la síntesis de $\beta$-galactosidasa. La producción máxima de $\beta$-galactosidasa por Chlorella sorokiniana IPR 7104, en condiciones heterótrofas y utilizando suero de queso como fuente de carbono, se obtiene utilizando las siguientes condiciones: temperatura $30^{\circ} \mathrm{C}$, concentración de etanol al $20 \%$ y tiempo de 4 min.

Palabras clave: Proceso biotecnológico; Microalgas; Condiciones de cultivo; Biomasa.

\section{Introduction}

It is remarkable that microalgae are photosynthetic organisms that can synthesize biomass as a potential source of bioenergy, food preparation and obtaining natural and bioactive compounds with high value in the marketplace (Sudhakar et al., 2019). It is also known that the cultivation of microalgae using waste from food processing becomes a challenge to be overcome because of its large-scale production and converting waste into a circular economy concept (Li et al., 2019; Yadav et al., 2020).

Additionally, microalgae show great potential to synthesis enzymes, as beta-galactosidase, however this use on an industrial scale still need more studies (Brasil et al., 2017). The beta-galactosidase enzyme catalyzes the hydrolysis of $\beta$-1,4-Dgalactosidic linkages of lactose, a disaccharide sugar from milk, into monosaccharides, galactose ad glucose (Anisha, 2017). The presence of lactose in milk and dairy products is responsible to lactose intolerance thus, the enzyme is used for the manufacture of low lactose products. The beta-galactosidase is widely present in the nature, e.g. plants, animals and microorganism, and enzyme structure may differ significantly in each genus (Bentahar et al., 2019; Xavier et al., 2018).

The microalgae cultivation conditions includes the following factors, natural or artificial light, CO2 (as carbon source), water, nitrogen sources and salts (Sakai et al., 1995; Welter et al., 2013). These parameters may vary according to the cultivation conditions adopted, and results in the following types of cultivation: autotrophic (rely on light energy to generate energy), heterotrophic (organic carbon sources are used for metabolism) or mixotrophic (combine autotrophic and heterotrophic) (Hui et al., 2017; Patel et al., 2019). Although few nutritional requirements are required, enzyme production by microalgae takes time since enzymes are produced intracellularly, requiring cell lysis for their extraction (Zanette et al., 2019). In a literature review, we can find studies on cultivation conditions used for beta-galactosidase production by microalgae (Suwal et al., 2019).

The study developed by Suwal et al. (2019) drew our attention because microalgal biomass growth rate and productivity cultivated in whey permeate (WP) was twice as much as obtained in regular medium, enriched Bold's Basal Medium (BBM). Higher biomass growth in WP was directly related to this medium composition and they concluded that further studies to optimize the microalgae growth conditions are needed.

The aim of this present study was optimized the better growth condition of Chlorella sorokiniana IPR 7104 to reach 
the maximum beta-galactosidase production.

\section{Methodology}

\subsection{Microalgae and cheese whey}

The inoculum of Chlorella sorokiniana IPR 7104 strain (Institute of Parana Rural Development, Londrina, Parana, Brazil) was activated in Bold's Basal Medium (BBM) containing $0.075 \mathrm{~g} \mathrm{~L}-1$ of K2HPO4, $0.175 \mathrm{~g} \mathrm{~L}-1$ of KH2PO4, $0.075 \mathrm{~g} \mathrm{~L}-$ 1 of $\mathrm{MgSO} 4.7 \mathrm{H} 2 \mathrm{O}, 0.25 \mathrm{~g} \mathrm{~L}-1$ of NaNO3, $0.025 \mathrm{~g} \mathrm{~L}-1$ of $\mathrm{CaCl} 2.2 \mathrm{H} 2 \mathrm{O}$ and $0.025 \mathrm{~g} \mathrm{~L}-1$ of NaCl. The inoculum was incubated at $28^{\circ} \mathrm{C}$ for 7 days in an orbital shaker (Tecnal®, TE-420, Brazil) at $150 \mathrm{rpm}$ with continuous lighting by LED lamp (4000 lux) and 12-hour photoperiod (light/dark). The cheese whey (supplied by Agropecuária Volpato Ltda, Arapongas, Parana, Brazil), was ultrafiltered in a tangential flow unit with $0.02 \mu \mathrm{m}$ diameter porosity to separate the whey protein ( $\beta$ lactoglobulina and $\alpha$-lactoalbumina).

\subsection{Growth conditions of Chlorella sorokiniana IPR 7104}

The microalgae growth was study under different conditions as shown in Table 1. All growth conditions tested were performed in an orbital shaker (Tecnal ${ }^{\circledR}$, TE-420, Brazil) at $150 \mathrm{rpm}, 28{ }^{\circ} \mathrm{C}$ for 7 days, in triplicate, with $10 \%$ inoculum (v/v) in $250 \mathrm{~mL}$ Erlenmeyer flasks with a volume of $100 \mathrm{~mL}$ of culture medium.

Table 1: Different growth conditions of Chlorella sorokiniana IPR 7104 with cheese whey.

\begin{tabular}{ll}
\hline Growth conditions & Medium \\
\hline Phototrophic & $\mathrm{BBM} *$ \\
Mixotrophic & $\mathrm{BBM}:$ cheese whey $(1: 1, \mathrm{v} / \mathrm{v})^{*}$ \\
Photoheterotrophic & Cheese whey* \\
Heterotrophic & Cheese whey** \\
\hline
\end{tabular}

*12-hour photoperiod (light/dark).

** Dark period only.

Source: Authors.

\subsection{Cells permeabilization of Chlorella sorokiniana IPR 7104}

For the optimization of the cells permeabilization, a Box-Behnken design (BBD) and Response Surface Methodology (RSM) was used with three variables and three replicates at the central points. The coded independent variables $\left(\mathrm{x}_{1}, \mathrm{x}_{2}\right.$ and $\left.\mathrm{x}_{3}\right)$ and uncoded variables $\left(\mathrm{X}_{1}=\%\right.$ ethanol, $\mathrm{X}_{2}={ }^{\circ} \mathrm{C}$ temperature, $\mathrm{X}_{3}=$ min time) are show in Table 3. The most appropriate growth condition evaluated in the previous experiment (Table 1) was considered to optimize the permeabilization of the microalgae cells. The assays were carried out in a $5 \mathrm{~L}$ Schott flask containing $2 \mathrm{~L}$ of deproteinized cheese whey with the addition of $10 \%$ inoculum during 7 days at $28^{\circ} \mathrm{C}$ and orbital shaker at $150 \mathrm{rpm}$ (Tecnal $®$, TE-420, Brazil). The $\beta$-galactosidase production was evaluated by $\beta$-galactosidase activity and with response function $\mathrm{Y}_{1}$ ( $\beta$-galactosidase activity, $\mathrm{U} \mathrm{mL}^{-1}$ ). The model equation was as follows:

$Y 1=\beta_{0}+\beta_{1} x_{1}+\beta_{2} x_{2}+\beta_{3} x_{3}+\beta_{1} x_{1}^{2}+\beta_{2} x_{2}^{2}+\beta_{3} x_{3}^{2}+\beta_{12} x_{1} x_{2}+\beta_{13} x_{1} x_{3}+\beta_{23} x_{2} x_{3}+e$

Where $Y_{1}$ (response function), $x_{1}, x_{2}$ and $x_{3}$, (coded variables), $\beta$ (estimated coefficients for each term of the response surface model). The response functions ( $\left.\mathrm{Y}_{1}\right)$ were used to perform regression analyses and analysis of variance (ANOVA) for the regression and were performed using Statistica 7.0 software (StatSoft Inc., 2007). 


\subsection{Cultivation condition of microalgae for $\beta$-galactosidase production}

The effect of cheese whey concentration $(\%)$, temperature $\left({ }^{\circ} \mathrm{C}\right)$ and $\mathrm{pH}$ growth condition of Chlorella sorokiniana IPR 7104 was optimized based in Box Behnken design model (BBD) and Response Surface Methodology (RSM). The coded independent variables $\left(\mathrm{x}_{1}, \mathrm{x}_{2}\right.$ and $\left.\mathrm{x}_{3}\right)$ and uncoded variables $\left(\mathrm{X}_{1}=\right.$ cheese whey concentration, \%), $\mathrm{X}_{2}={ }^{\circ} \mathrm{C}$ temperature, $\mathrm{X}_{3}=$ $\mathrm{pH}$ ) and four replicates at the central point's resulting in 15 assays, shown in Table 5.

The assays were carried out in a $250 \mathrm{~mL}$ Schott flask containing $100 \mathrm{~mL}$ of pasteurized cheese whey with the addition of $10 \%$ inoculum during 7 days at $28^{\circ} \mathrm{C}$ on orbital shaker at $150 \mathrm{rpm}$ (Tecnal ${ }^{\circledR}, \mathrm{TE}-420$, Brazil). The $\beta$-galactosidase production was evaluated by $\beta$-galactosidase activity and with response function $\mathrm{Y}_{1}\left(\beta\right.$-galactosidase activity, $\mathrm{U} \mathrm{mL}^{-1}$ ). The model equation was as follows:

$Y 1=\beta_{0}+\beta_{1} x_{1}+\beta_{2} x_{2}+\beta_{3} x_{3}+\beta_{1} x_{1}^{2}+\beta_{2} x_{2}^{2}+\beta_{3} x_{3}^{2}+\beta_{12} x_{1} x_{2}+\beta_{13} x_{1} x_{3}+\beta_{23} x_{2} x_{3}+e$

Where $\mathrm{Y}_{1}$ (response function), $\mathrm{x}_{1}, \mathrm{x}_{2}$ and $\mathrm{x}_{3}$, (coded variables), $\beta$ (estimated coefficients for each term of the response surface model). The response functions $\left(\mathrm{Y}_{1}\right)$ were used to perform regression analyses and analysis of variance (ANOVA) for the regression and were performed using Statistica 7.0 software (StatSoft Inc., 2007).

\subsection{Cultivation kinetics of Chlorella sorokiniana IPR 7104}

The kinetics were performed in a $5 \mathrm{~L}$ Schott bottle containing $2 \mathrm{~L}$ of permeated cheese whey with a concentration of $36 \mathrm{~g} \mathrm{~L}^{-1}$ of lactose, $\mathrm{pH} 6.0$, pasteurized at $65^{\circ} \mathrm{C}$ for $30 \mathrm{~min}$ and inoculated with $10 \%\left(\mathrm{v} \mathrm{v}^{-1}\right)$ of inoculum. The cultivation was carried out at $28^{\circ} \mathrm{C}, 150 \mathrm{rpm}$ for 12 days. Every $24 \mathrm{~h}, 100 \mathrm{~mL}$ were collected and enzyme activity, residual lactose content and biomass production were quantified.

\subsection{Lactose estimation}

The lactose estimation was carried out, in triplicate, following the methodology described by Nickerson et al. (1975). $5 \mathrm{~mL}$ of glycine- $\mathrm{NaOH}$ buffer, $0.5 \mathrm{~mL}$ of methylamine-HCL and $0.5 \mathrm{~mL}$ of sodium sulfite solution were added to $5 \mathrm{~mL}$ of samples. The samples were thoroughly mixed and kept at $65{ }^{\circ} \mathrm{C}$ in water bath for $25 \mathrm{~min}$. After cooling, the samples were transferred immediately to an ice-water bath for $2 \mathrm{~min}$. The absorbance of the sample was taken at $540 \mathrm{~nm}$ on spectrophotometer (Biochrom libra S22 Cambridge England). The result $\left(\mathrm{g} \mathrm{L}^{-1}\right)$ was determined by the difference between initial and final content.

\subsection{Biomass content}

The samples were filtered using $0.45 \mu \mathrm{m}$ membrane filters. The cells on the filter (biomass) were then rinsed with distilled water and overnight dried in an oven at $105{ }^{\circ} \mathrm{C}$. The biomass was quantified gravimetrically, in triplicate. The microalgae cells were transferred to porcelain mortar and fresh weight was measured. Then, the cells were placed in an oven at $105^{\circ} \mathrm{C}$. The biomass weight $\left(\mathrm{g} \mathrm{L}^{-1}\right)$ was calculated by the difference between initial weight $(\mathrm{g})$ and final weight of dry cells.

\section{$2.8 \beta$-galactosidase activity}

The $\beta$-galactosidase activity was determined, in permeabilized microalgae cells by the amount of glucose released by the enzyme in a standard lactose solution. Glucose content was determined by the colorimetric glucose-oxidase method (Bioliquid®). Approximately, $5 \%(\mathrm{v} / \mathrm{v})$ of permeabilized cells were added in a lactose solution $(5 \%, \mathrm{w} / \mathrm{v}) 50 \mathrm{~g} \mathrm{~L}^{-1}$, prepared in phosphate buffer $0.1 \mathrm{M}, \mathrm{pH} 6.8$ and incubated at $37^{\circ} \mathrm{C}$ for 6 hours, followed by enzyme inactivation at $90{ }^{\circ} \mathrm{C}$ for $5 \mathrm{~min}$. The 
glucose concentration was determined by the glucose-oxidase method (Bioliquid®). The calculation of glucose concentration (GC) was performed using the following equation:

$$
G C\left(m g d L^{-1}\right)=\frac{A B S}{P} \times 100
$$

Where $\mathrm{GC}=$ glucose concentration, $\mathrm{ABS}=$ absorbance and $\mathrm{P}=$ standard.

The calculation of enzymatic activity (EA) was performed by the equation

$E A\left(U m L^{-1}\right)=\frac{G C}{M W G} \div T$

Where MWG $=$ molecular weight of glucose and $\mathrm{T}=$ time $(\min$.$) .$

\section{Results and Discussion}

\subsection{Growth conditions of Chlorella sorokiniana IPR 7104}

The growth conditions of microalgae besides glucose, also realized in the presence of the other organic carbon sources, with or without light, depending on each type of microalgae to be explored. To verify the best growth conditions, it is necessary to make a study under all conditions. In this study, Chlorella sorokiniana IPR 7104 cultivated at heterotrophic conditions, containing cheese whey with initial concentration of $35.5 \mathrm{~g} \mathrm{~L}-1$ of lactose showed $10.3 \mathrm{~g} \mathrm{~L}-1$ of biomass (Table 2), and after 7 days, residual lactose was only $3.4 \mathrm{~g} \mathrm{~L}-1$, due to hydrolysis by the $\beta$-galactosidase enzyme. Values of biomass similar were obtained to our results when exploring a new phycoremediation strategy to convert a dairy by-product as cheese whey permeate into microalgal biomass with Scenedesmus obliquus and Chlorella protothecoides (Girard et al., 2014; Xiong et al., 2008). Other studies also indicated heterotrophic growth for cultivating microalgae with higher productivity gains in biomass when compared to conventional photosynthetic systems (Yeh et al., 2012; Salati et al., 2017). The use of cheese whey as culture medium, contributes to lower the costs of the microalgae cultivation process since this product is a waste of dairy industry and has a high lactose (Bekirogullari et al., 2020). Under photoautotrophic conditions, using BBM medium and a 12hour photoperiod, the biomass yield was lower when compared to the other conditions. In addition, there was no enzymatic activity, probably due to the absence of lactose in the medium. Therefore, based on our results, the cultivation condition chosen to Chlorella sorokiniana IPR 7104 was the heterotrophic, which showed the major enzymatic activity, consequently a lower residual lactose content. 
Table 2: Biomass production, residual glucose, lactose consumption and $\beta$-galactosidase activity of different growth conditions of Chlorella sorokiniana IPR 7104.

\begin{tabular}{|c|c|c|c|}
\hline Growth conditions & $\begin{array}{l}\text { Enzymatic activity } \\
\text { U.mL } \mathrm{mL}^{-1} \pm(\mathrm{dpm})\end{array}$ & $\begin{array}{l}\text { Lactose residual } \\
\text { g.L } \mathrm{L}^{-1} \pm(\mathrm{dpm})\end{array}$ & $\begin{array}{l}\text { Biomass } \\
\text { g. } \mathrm{L}^{-1} \pm(\mathrm{dpm})\end{array}$ \\
\hline Phototrophic & $0.000 \pm(0.000)^{\mathrm{d}}$ & $0.000 \pm\left(0.000^{) d}\right.$ & $8.241 \pm(0.174)^{\mathrm{c}}$ \\
\hline Mixotrophic & $0.021 \pm(0.005)^{\mathrm{c}}$ & $3.638 \pm(0.122)^{\mathrm{b}}$ & $10.166 \pm(9.935)^{b}$ \\
\hline Photoheterotrophic & $0.050 \pm(0.006)^{\mathrm{b}}$ & $4.545 \pm(0.052)^{\mathrm{a}}$ & $11.050 \pm(0.334)^{\mathrm{a}}$ \\
\hline Heterotrophic & $0.090 \pm(0.012)^{\mathrm{a}}$ & $3.408 \pm(0.038)^{\mathrm{c}}$ & $10.275 \pm(0.302)^{a b}$ \\
\hline
\end{tabular}

Different letters in the same column indicate differences by tukey test $(\mathrm{p}<0.05)$ between treatments. Deviation-standard mean $(\mathrm{dpm})$. Source: Authors.

\subsection{Cells permeabilization of Chlorella sorokiniana IPR 7104}

From the exploratory model of the first Box-Behnken Design (BBD) (Table 3), the ANOVA and regression analysis (Table 4), the effects of variables $\mathrm{X}_{1}$ (ethanol, \%), $\mathrm{X}_{2}$ (permeabilization temperature, ${ }^{\circ} \mathrm{C}$ ) and $\mathrm{X}_{3}$ (time, min) were observed. The linear and quadratic effects of the variables $\mathrm{X}_{1}$ (ethanol, \%) and $\mathrm{X}_{2}$ (permeabilization temperature, ${ }^{\circ} \mathrm{C}$ ) were significant and none of the interactions $\left(\left(\mathrm{X}_{1} \mathrm{X}_{2}, \mathrm{X}_{1} \mathrm{X}_{3}\right.\right.$ and $\left.\mathrm{X}_{2} \mathrm{X}_{3}\right)$ were significant. The model showed a no significant lack of fit (at $95 \%$ ) and approximately $94 \%\left(\mathrm{R}^{2}\right)$ of the experimental data was properly adjusted to the model.

Table 3: Box-Behnken Design (BBD) for Chlorella sorokiniana IPR 7104 cells permeabilization and response function $\mathrm{Y}_{1}$.

\begin{tabular}{|c|c|c|c|c|}
\hline Assays & $\begin{array}{c}\text { Independent variables coded } \\
\text { and uncoded } \\
\mathrm{X}_{1}\left(\mathbf{x}_{1}\right)\end{array}$ & $\mathbf{X}_{2}\left(\mathbf{x}_{2}\right)$ & $\mathbf{X}_{\mathbf{3}}\left(\mathbf{x}_{3}\right)$ & $\begin{array}{c}\text { Response Function } \\
\mathrm{Y}_{1}\end{array}$ \\
\hline 1 & $-1(10)$ & $-1(30)$ & $0(8)$ & 1.2742 \\
\hline 2 & $+1(30)$ & $-1(30)$ & $0(8)$ & 1.231 \\
\hline 3 & $-1(10)$ & $+1(50)$ & $0(8)$ & 1.2512 \\
\hline 4 & $+1(30)$ & $+1(50)$ & $0(8)$ & 0.8746 \\
\hline 5 & $-1(10$ & $0(40)$ & $-1(4)$ & 1.4834 \\
\hline 6 & $+1(30)$ & $0(40)$ & $-1(4)$ & 1.2998 \\
\hline 7 & $-1(10)$ & $0(40)$ & $+1(12)$ & 1.3066 \\
\hline 8 & $+1(30)$ & $0(40)$ & $+1(12)$ & 1.3079 \\
\hline 9 & $0(20)$ & $-1(30)$ & $-1(4)$ & 1.6224 \\
\hline 10 & $0(20)$ & $+1(50)$ & $-1(4)$ & 1.2215 \\
\hline 11 & $0(20)$ & $-1(30)$ & $+1(12)$ & 1.5576 \\
\hline 12 & $0(20)$ & $+1(50)$ & $+1(12)$ & 1.0879 \\
\hline 13 & $0(20)$ & $0(40)$ & $0(8)$ & 1.6129 \\
\hline 14 & $0(20)$ & $0(40)$ & $0(8)$ & 1.5347 \\
\hline 15 & $0(20)$ & $0(40)$ & $0(8)$ & 1.5563 \\
\hline
\end{tabular}

$\mathrm{X}_{1}\left(\right.$ ethanol, \%); $\mathrm{X}_{2}$ (temperature of permeabilization, $\left.{ }^{\circ} \mathrm{C}\right) ; \mathrm{X}_{3}$ (time of permeabilization, min) and $\mathrm{Y}_{1}\left(\mathrm{U}^{\mathrm{mL}}{ }^{-1} \beta\right.$-galactosidase activity). Source: Authors.

Considering the heterotrophic growth conditions for Chlorella sorokiniana IPR 7104, we was observed (Table 3 ) that enzymatic activity was higher in assay $9\left(\mathrm{Y}_{1}=1.62 \mathrm{U} \mathrm{mL}^{-1}\right)$, followed by assay $13\left(\mathrm{Y}_{1}=1.61 \mathrm{U}^{-1}\right)($ central point). These observations indicate that permeabilization process depend on the time during investigated range, confirming that variable $\mathrm{X}_{3}$ has significant effect on this process. Thus, we decide considering the complete model. The model proposed can be described as follows:

$Y_{1}=1,292500-0,150000 x_{1}-0,312500 x_{2}-0,087500 x_{3}+0,217083 x_{1}^{2}+0,194583 x_{2}^{2}-0,000417 x_{a}^{2}-0,170000 x_{1} x_{2}+$ $0,090000 x_{1} x_{3}-0,035000 x_{2} x_{3}+0,016333$ 
Table 4: ANOVA for cell permeabilization of Chlorella sorokiniana IPR 7104.

\begin{tabular}{llllll}
\hline Sources of variation & SS & DF & MS & F & P value \\
\hline $\mathbf{X}_{\mathbf{1}}$ (linear and quadratic) & $0.22^{*}$ & $2 *$ & $0.109^{*}$ & $67.041^{*}$ & $0.015^{*}$ \\
$\mathbf{X}_{\mathbf{2}}$ (linear and quadratic) & $0.34^{*}$ & $2 *$ & $0.168^{*}$ & $102.586^{*}$ & $0.009^{*}$ \\
$\mathbf{X 3}$ (linear and quadratic) & 0.015 & 2 & 0.008 & 4.688 & 0.176 \\
$\mathbf{X}_{\mathbf{1}} \mathbf{X}_{2}$ & 0.029 & 1 & 0.029 & 17.694 & 0.052 \\
$\mathbf{X}_{\mathbf{1}} \mathbf{X}_{3}$ & 0.008 & 1 & 0.008 & 4.959 & 0.156 \\
$\mathbf{X}_{\mathbf{2}} \mathbf{X}_{3}$ & 0.001 & 1 & 0.001 & 0.750 & 0.478 \\
Lack of fit & 0.004 & 3 & 0.012 & 7.617 & 0.118 \\
Error & 0.003 & 2 & 0.001 & & \\
Total & 0.629 & 14 & & & \\
\hline
\end{tabular}

*significant at $5 \%$ by Tuckey test. Source: Authors.

Analyzing the mathematical model for the response function $\mathrm{Y}_{1}(\beta$-galactosidase) and the response surface Figure 1a, it was observed that there is a region in which the enzyme activity is greater than $1.4 \%$ in permeabilized cells, i.e., $\mathrm{x}_{2}$ was between 30 and $40{ }^{\circ} \mathrm{C}$ and the ethanol concentration $\mathrm{x}_{1}$ was between 10 and $30 \%$ during process. In the Figure $1 \mathrm{~b}$, it was observed that there is a region in which the enzyme activity is greater than $1.6 \%$, i.e., $\mathrm{x}_{3}$ was between 4 and 8 min and ethanol concentration was 10 and $30 \%$; in the Figure 1c, the major enzyme activity (>1.4) was observed when temperature $\mathrm{x}_{2}$ was between 30 and 40 and $x_{3}$, time, was between 4 and 12 min.

Figure 1: Response surface: (a) percentage $\beta$-galactosidase as function of temperature $\left({ }^{\circ} \mathrm{C}\right)$ and ethanol (\%); (b) as function of time (min) and ethanol $\left({ }^{\circ} \mathrm{C}\right)$ and $(\mathrm{c})$ as function of temperature $\left({ }^{\circ} \mathrm{C}\right)$ and time (min).

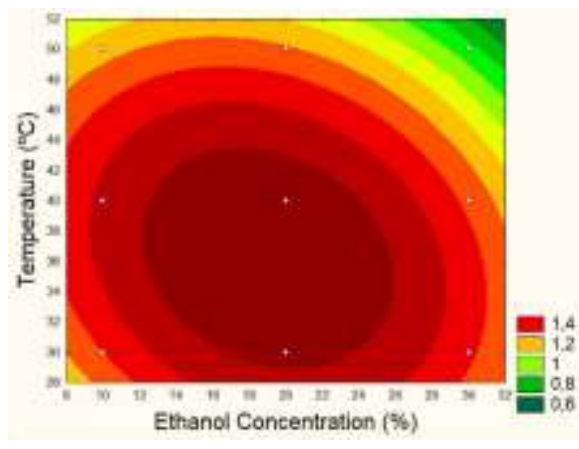

(a)

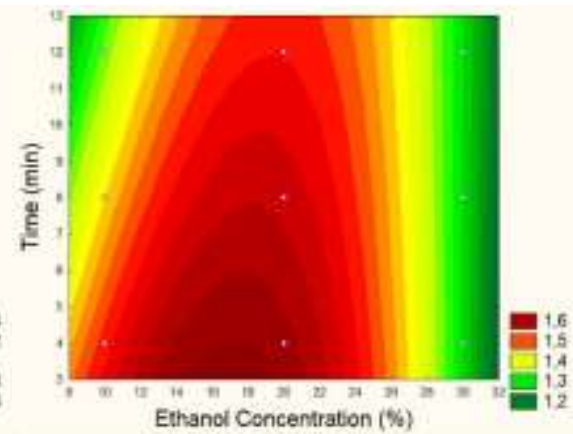

(b)

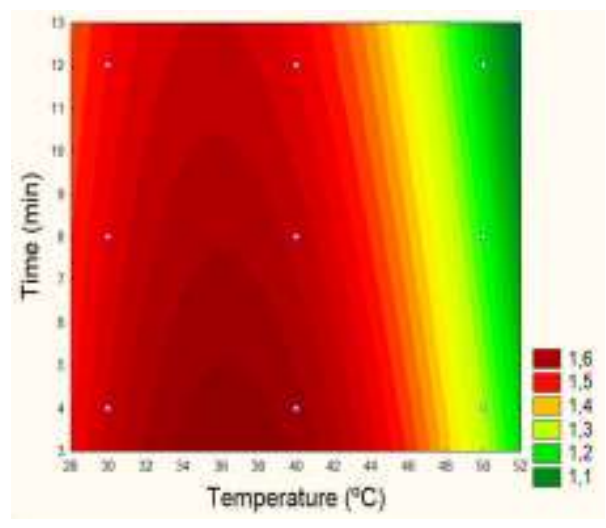

(c)

Source: Authors. 
Figure 2. Response surface: (a) percentage $\beta$-galactosidase as function of cheese whey concentration (\%) and temperature $\left({ }^{\circ} \mathrm{C}\right)$; (b) as function of cheese whey concentration $(\%)$ and $\mathrm{pH}$ and $(\mathrm{c})$ as function of temperature $\left({ }^{\circ} \mathrm{C}\right)$ and $\mathrm{pH}$.

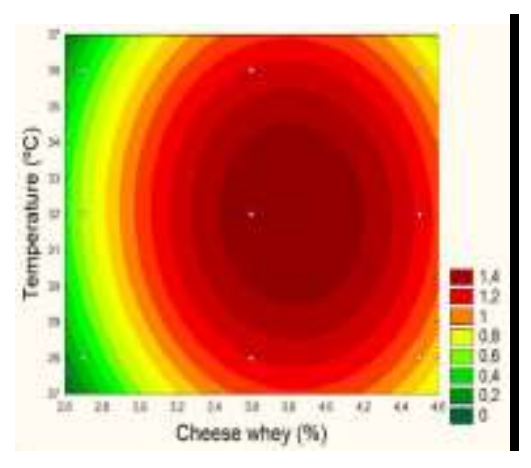

(a)

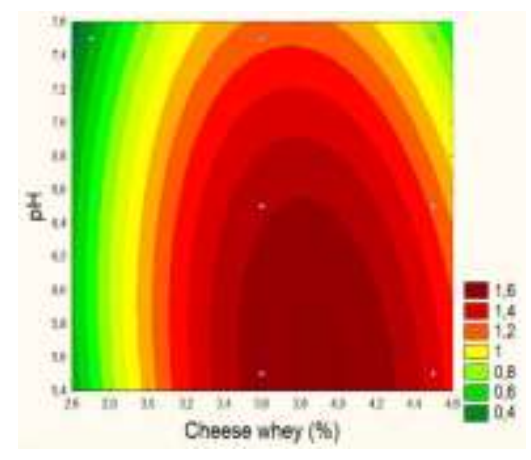

(b)

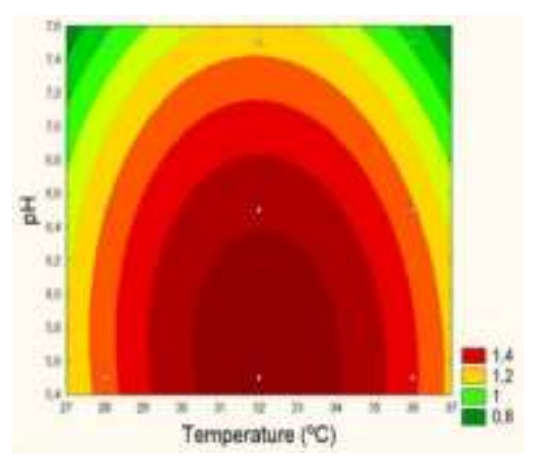

(c)

Source: Authors.

The maximum $\beta$-galactosidase production by Chlorella sorokiniana IPR 7104 permeabilized cells was obtained using the conditions of $30^{\circ} \mathrm{C}$, concentration of ethanol at $20 \%$ and $4 \mathrm{~min}$.

\subsection{Cultivation condition of microalgae for $\beta$-galactosidase production}

From the exploratory model of the first Box-Behnken Design (BBD) (Table 5), the ANOVA and the regression analysis (Table 6), the effects, linear and quadratic, of $\mathrm{X}_{1}$ (cheese whey concentration, $\mathrm{g} \mathrm{L}^{-1}$ ); $\mathrm{X}_{2}\left(\right.$ temperature, $\left.{ }^{\circ} \mathrm{C}\right) ; \mathrm{X}_{3}(\mathrm{pH})$ were significant. The interaction $\mathrm{X}_{1} \mathrm{X}_{3}$ was significant. The model showed a non-significant lack of fit (at 95\%) and approximately $98 \%\left(\mathrm{R}^{2}\right)$ of the experimental data was properly adjusted to the model. 
Table 5: Box-Behnken Design (BBD) for cultivation condition of Chlorella sorokiniana IPR 7104 and response function $\mathrm{Y}_{2}$.

\begin{tabular}{|c|c|c|c|c|}
\hline \multirow[b]{2}{*}{ Assays } & \multicolumn{3}{|c|}{ Independent variables coded and uncoded } & \multirow{2}{*}{$\begin{array}{c}\text { Response Function } \\
\mathrm{Y}_{2}\end{array}$} \\
\hline & $\mathbf{X}_{1}\left(\mathbf{x}_{1}\right)$ & $\mathbf{X}_{2}\left(\mathbf{x}_{2}\right)$ & $\mathbf{X}_{\mathbf{3}}\left(\mathbf{x}_{3}\right)$ & \\
\hline 1 & $-1(27)$ & $-1(28)$ & $0(6.5)$ & 0.31 \\
\hline 2 & $+1(45)$ & $-1(28)$ & $0(6.5)$ & 0.86 \\
\hline 3 & $-1(27)$ & $+1(36)$ & $06.5)$ & 0.44 \\
\hline 4 & $+1(45)$ & $+1(36)$ & $0(6.5)$ & 0.89 \\
\hline 5 & $-1(27)$ & $0(32)$ & $-1(5.5)$ & 0.53 \\
\hline 6 & $+1(45)$ & $0(32)$ & $-1(5.5)$ & 1.32 \\
\hline 7 & $-1(27)$ & $0(32)$ & $+1(7.5)$ & 0.44 \\
\hline 8 & $+1(45)$ & $0(32)$ & $+1(7.5)$ & 0.86 \\
\hline 9 & $0(36)$ & $-1(28)$ & $-1(5.5)$ & 1.35 \\
\hline 10 & $0(36)$ & $+1(36)$ & $-1(5.5)$ & 1.35 \\
\hline 11 & $0(36)$ & $-1(28)$ & $+1(7.5)$ & 0.87 \\
\hline 12 & $0(36)$ & $+1(36)$ & $+1(7.5)$ & 0.79 \\
\hline 13 & $0(36)$ & $0(32)$ & $0(6.5)$ & 1.45 \\
\hline 14 & $0(36)$ & $0(32)$ & $0(6.5)$ & 1.48 \\
\hline 15 & $0(36)$ & $0(32)$ & $0(6.5)$ & 1.49 \\
\hline
\end{tabular}

$\mathrm{X}_{1}$ (cheese whey concentration, $\left.\mathrm{g} \mathrm{L}^{-1}\right) ; \mathrm{X}_{2}$ (temperature, $\left.{ }^{\circ} \mathrm{C}\right) ; \mathrm{X}_{3}(\mathrm{pH})$ and $\mathrm{Y}_{2}\left(\beta\right.$-galactosidase activity, $\left.\mathrm{U} \mathrm{mL}^{-1}\right)$. Source: Authors.

Table 6: ANOVA for cultivation conditions for Chlorella sorokiniana IPR 7104.

\begin{tabular}{llllll}
\hline Sources of variation & SS & DF & MS & F & P value \\
\hline $\mathbf{X}_{1}$ (linear and quadratic) & $1.858^{*}$ & $2^{*}$ & $0.929^{*}$ & $1327.016^{*}$ & $0.001^{*}$ \\
$\mathbf{X}_{\mathbf{2}}$ (linear and quadratic) & $0.275^{*}$ & $2 *$ & $0.137^{*}$ & $196.162^{*}$ & $0.005^{*}$ \\
$\mathbf{X 3}$ (linear and quadratic) & $0.359^{*}$ & $2 *$ & $0.179^{*}$ & $256.272^{*}$ & $0.004^{*}$ \\
$\mathbf{X}_{\mathbf{1}} \mathbf{X}_{\mathbf{2}}$ & 0.003 & 1 & 0.003 & 3.571 & 0.199 \\
$\mathbf{X}_{\mathbf{1}} \mathbf{X}_{\mathbf{3}}$ & $0.036^{*}$ & $1 *$ & $0.036^{*}$ & $51.571^{*}$ & $0.019^{*}$ \\
$\mathbf{X}_{\mathbf{2}} \mathbf{X}_{\mathbf{3}}$ & 0.002 & 1 & 0.002 & 3.571 & 0.199 \\
$\mathbf{L a c k}$ of fit & 0.040 & 3 & 0.013 & 19.000 & 0.050 \\
Error & 0.001 & 2 & 0.001 & & \\
Total & 2.455 & 14 & & & \\
\hline
\end{tabular}

Source: Authors.

Considering the heterotrophic cultivation conditions for Chlorella sorokiniana IPR 7104, we observed on Table 5 that enzymatic activity $\left(\mathrm{U} \mathrm{mL} \mathrm{m}^{-1}\right)$ was higher in assay $15\left(\mathrm{Y}_{2}=1.49 \mathrm{U} \mathrm{mL}^{-1}\right)$ under the following conditions: cheese whey concentration of $36 \mathrm{U} \mathrm{mL}^{-1}$, temperature of $32{ }^{\circ} \mathrm{C}$ and $\mathrm{pH}$ equal 6.5 . These results were followed by assay $14\left(1.48 \mathrm{U} \mathrm{mL}^{-1}\right)$ and $13\left(1.45 \mathrm{U} \mathrm{mL}^{-1}\right)$ considered the central points. The model proposed is described as follows:

$Y_{2}=0,833531+0,552113 x_{1}-0,015076 x_{2}-0,392213 x_{3}+0,581612 x_{1}^{2}+0,273445 x_{2}^{2}+0,113307 x_{a}^{2}-0,050570 x_{1} x_{2}+$ $0,187559 x_{1} x_{3}-0,048433 x_{2} x_{3}+0,004897$

Analyzing the mathematical model for the response function $\mathrm{Y}_{2}(\beta$-galactosidase activity) and the response surface Figure $2 \mathrm{a}$, it was observed that there is a region in which the enzyme activity is greater than $1.4 \mathrm{U} \mathrm{mL}^{-1}$ when the cheese whey 
concentration was between 36 and $44 \%$ and the temperature was between 28 and $36^{\circ} \mathrm{C}$. In the Figure $2 \mathrm{~b}$, it was observed that there is a region in which the enzyme activity is greater than $1.6 \mathrm{U} \mathrm{mL}^{-1}$, i.e., $\mathrm{x}_{1}$ was between 36 and $44 \mathrm{U} \mathrm{mL}^{-1}$ and $\mathrm{pH}$ was 5.4 and 7.4; in the Figure 2c, the major enzyme activity (>1.4) was observed when temperature $\mathrm{x}_{2}$ was between 32 and $36{ }^{\circ} \mathrm{C}$ and $\mathrm{x}_{3}, \mathrm{pH}$, was between 5.4 and 6.5 .

\subsection{Cultivation kinetics of Chlorella sorokiniana IPR 7104}

The fermentation kinetics of $C$. sorokiniana IPR 7104 in heterotrophic condition (without light) was evaluated for 12 days, and results indicated that until 8th day, $\beta$-galactosidase activity increased linearly up to $1.40 \mathrm{U} \mathrm{mL}^{-1}$ (Figure 3). Biomass production grew linearly at rate of $0.35 \mathrm{~g} \mathrm{~L}^{-1}$ per day until $12.02 \mathrm{~g} \mathrm{~L}^{-1}$ on the 12 th day. The microalgae consumed $89.6 \%$ of lactose in 3 days, showing a high capacity to metabolize this disaccharide, through $\beta$-galactosidase synthesis. This mechanism is observed to a lesser extent when cultivation is carried out in the presence of light, as occurred in mixotrophic and photoheterotrophic cultivation.

Figure 3. Growth curve of microalgae grown in cheese whey under heterotrophic conditions.

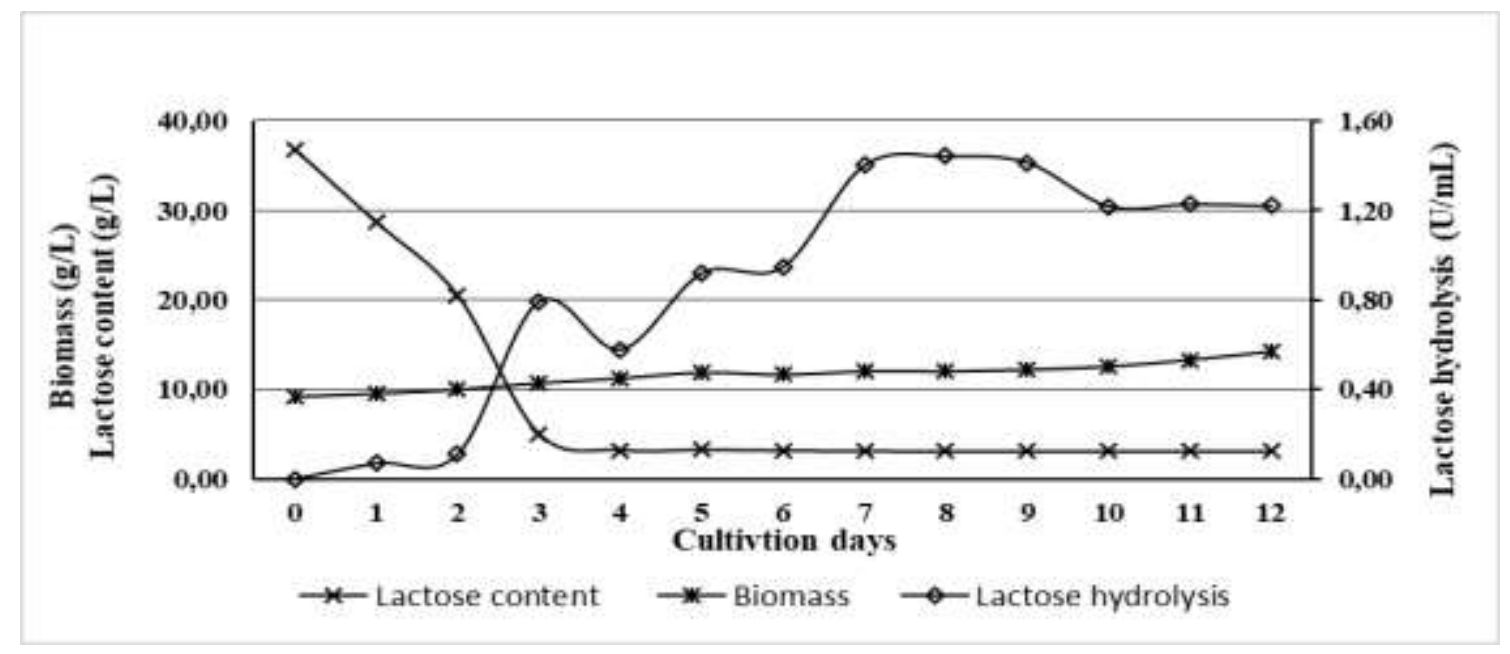

Source: Authors.

Model-based optimized conditions have been established for minimal cultivation costs and time, or maximal microalgae productivities, which highlight the applicability of kinetic models as powerful optimization and scaling-up tools. Thinking about this, is very important the cultivation kinetics study of microalgae.

Many researchers have studied processes that use waste generated by industry or agricultural activity for the production of microalgae biomass. Herold et al. (2021), for example, worked with Tetraselmis suecica concluded that anaerobically-digested piggery effluent can be used not only as an asset but also uses an impurity (CO2) in biogas to produce valuable algal biomass. Within circular economy, we can develop process to maximum biomass production and application in biotechnology.

\section{Conclusion}

The maximum $\beta$-galactosidase production by Chlorella sorokiniana IPR 7104, in heterotrophic conditions and using cheese whey as carbon source, is obtained using the following conditions: $30^{\circ} \mathrm{C}$ temperature, concentration of ethanol at $20 \%$ and time of 4 min. 


\section{References}

Anisha, G. S. (2017). $\beta$-galactosidases. In: Pandey, A.; Negi, S.; Soccol, C.R. Current developments in biotechnology and bioengineering: production, isolation and purification of industrial products. Elsevier 17, 395-421. https://doi.org/10.1016/B978-0-444-63662-1.00017-8

Brasil, B. S. A. F., Siqueira, F. G., Salum, T. F. C., Zanette, C. M., \& Spier, M. R. (2017). Microalgae and cyanobacteria as enzyme biofactories. Algal Research. 25, 76-89.

Bentahar, J., Doyen, A., Beaulieu, L., \& Deschênes, J.S. (2019). Investigation of $\beta$-galactosidase production by microalga Tetradesmus obliquus in determined growth conditions. J. Appl. Phycol. 31, 301-308. https://doi.org/10.1007/s10811-018-1550-y

Bekirogullari, M., Figueroa-Torres, G. M., Pittman, J. K., \& Theodoropoulos, C. (2020). Models of microalgal cultivation for added-value products - A review. Biotechnology Advances. 44, 07609. https://doi.org/10.1016/j.biotechadv.2020.107609.

Girard, J. M., Roy, M. L., Hafsa, M. B., Gagnon, J., Faucheux, N., Heitz, M., Tremblay, R., \& Deschenes, J. S. (2014). Mixotrophic cultivation of green microalgae Scenedesmus obliquus on cheese whey permeate for biodiesel production. Algal Res. 5, 241-248.

Herold, C., Ishika, T., Nwoba, E.G., Tait, S., Ward, A., \& Moheimani, N.R. (2021). Biomass production of marine microalga Tetraselmis suecica using biogas and wastewater as nutrients, Biomass and Bioenergy. 145, 105945. https://doi:10.1016/j.biombioe.2020.105945.

Hui, W., Wenjun, Z., Huimin, S., \& Tianzhong, L. (2017). A comparative analysis of biomass and lipid content in five Tribonema sp. strains at autotrophic, heterotrophic and mixotrophic cultivation. Algal Research. 24, 284-289, https://doi.org/10.1016/j.algal.2017.04.020.

Li, S., Zhao, S., Yan, S., Qiu, Y., Song, C., Li, Y., \& Kitamura, Y. (2019). Food processing wastewater purification by microalgae cultivation associated with high value-added compounds production-a review. Chinese Journal of Chemical Engineering, 27(12), $2845-2856$.

Nickerson, T. A., Vujicic, I. F., \& Lin, A.Y. (1975). Colorimetric estimation of lactose and its hydrolytic products. J. Dairy Sci. (Champaign) 59 (3), 386-90. Patel, A. K., Joun, J. M., Hong, M. E., \& Sim, S. J. (2019). Effect of light conditions on mixotrophic cultivation of green microalgae. Bioresource Technology. $282,245-253$.

Sakai, N., Sakamoto, Y., Kishimoto, N., Chihara, M., \& Karube, I. (1995). Chlorella strains from hot springs tolerant to high temperature and high CO 2 . Energy Convers. Manag. 36 (6), 693-696.

Salati, S., D'Imporzano, G., Menin, B., Veronesi, D., Scaglia, B., Abbruscato, P., Mariani, P., \& Adani, F. (2017). Mixotrophic cultivation of Chlorella for local protein production using agro-food by-products. Bioresource Technology. 230, 82-89. https://doi.org/10.1016/j.biortech.2017.01.030.

Sudhakar, M. P., Kumar, B. R., Mathimani, T., \& Arunkumar, K. (2019). A review on bioenergy and bioactive compounds from microalgae and macroalgaesustainable energy perspective. Journal of Cleaner Production, 228.

Suwal, S., Bentahar, J., Marciniak, A., Beaulieu, L., Deschenes, J. S., \& Doyen, A. (2019). Evidence of the production of galactooligosaccharide from whey permeate by the microalgae Tetradesmus obliquus. Algal Res. 39, 101470. https://doi.org/10.1016/j.algal.2019.101470

Welter, C., Schwenk, J., Kanani, B., Van Blargan, J., \& Belovich, J.M. (2013). Minimal médium for optimal growth and lipid production of the microalgae Scenedesmus dimorphus. Environ. Prog. Sustain. Energy. 32 (4), 937-945.

Xavier, J. R., Ramana, K.V., \& Sharma, R. K. (2018). B-galactosidase: Biotechnological applications in food processing. J. Food Biochem. 42, e12564. https://doi.org/10.1111/jfbc. 12564

Xiong, W., Li, X. F., Xiang, J. Y., \& Wu, Q. Y. (2008). High-density fermentation of microalga Chlorella protothecoides in bioreactor for microbial-diesel production. Appl. Microbiol. Biotechnol. 78, 29-36.

Yadav, G., Panda, S. P., \& Sen, R. (2020). Strategies for the effective solid, liquid and gaseous waste valorization by microalgae: A circular bioeconomy perspective. J. Environ. Chem. Eng., 8 (6), 104518.

Yeh, K. L., Chen, C. Y., \& Chang, J. S. (2012). pH-stat photoheterotrophic cultivation of indegenous Chlorella vulgaris ESP-31 for biomass and lipid production using acetic acid as the carbon source. Journal Biochem. Engineering. 64, 1-7.

Zanette, C. M., Mariano, A. B., Yukawa, Y. S., Mendes, I. \& Spier, M. R. (2019). Microalgae mixotrophic cultivation for $\beta$-galactosidase production. Journal of Applied Phycology. 31, 1597-1606. https://doi.org/10.1007/s10811-018-1720-y 